\title{
THE FORMATION OF ANODIC LAYERS ON ANNEALED COPPER SURFACES IN PHOSPHATE- CONTAINING SOLUTIONS AT DIFFERENT $\mathrm{pH}$
}

\author{
M M Laz, R M Souto, S González, R C Salvarezza* and A J Arvia* \\ Departamento de Quimica Físıca, Universidad de La Laguna, Tenenfe, Spain
}

(Received 28 May 1991, in revised form 11 July 1991)

\begin{abstract}
The electrochemical behaviour of $\mathrm{Cu}$ in different phosphate buffers is studied through electrochemical techniques combined with scanning electron microscopy and energy dispersive X-ray analysis At pH 60 and 80 the onset of passivation is due to the anodic formation of a basic $\mathrm{Cu}$ (II) phosphate, whereas at pH 115 the passivating layer corresponds to a duplex $\mathrm{Cu}(\mathrm{I})$ oxide-Cu(II) oxide layer The potentiostatic anodic current transients can be reproduced by a model involving the initial growth of a thin anodic layer and the simultaneous electrodissolution of $\mathrm{Cu}$ The electrodissolution of passivated $\mathrm{Cu}$ takes place through the passivating layer This reaction contributes to the thickening of the outer part of the passivating layer
\end{abstract}

Key words anodic layers, copper passivation, phosphate solutions, growth mechanism, duplex-type passive layers

\section{INTRODUCTION}

The study of the electrochemical behaviour of $\mathrm{Cu}$ in phosphate-containing solutions has been mainly focussed on $\mathrm{Cu}$ electropohshing in concentrated phosphonc acid[1-6] Different aspects of this process such as the contribution of transport processes[7,8], the formation of anodic layers[9-14], and the appearance of photoeffects during electropolishing[15-19] have been investigated by employing different electrochemical and surface analysis techniques Nevertheless, there are still a number of problems emerging from the inherent complexity of the system which remain open for further research work

A detailed survey of the literature, partıcularly that corresponding to the current-potential curves shows that $\mathrm{Cu}$ pitting and $\mathrm{Cu}$ electropolishing appear as two processes which are to some extent interrelated, at least within a certain transition potential range Furthermore, the kinetics of the corrosion and passivation of relatively soft metals such as $\mathrm{Cu}$, in addition to the influence of the electrolyte solution composition, depends also on the initial metallurgical and mechanical treatments of the specimens. For a clear understanding of these questions a systematic work in different electrolytes with a standardized $\mathrm{Cu}$ specimen is necessary

The present work is devoted to investigating the reactions related to the anodization of $\mathrm{Cu}$ in phosphate-containing buffered solutions at different $\mathrm{pH}$ values, and to determine the type of anodic layers which are formed under different conditions.

*Visiting Professor, Consejo Nacional de Investigaciones Cientificas y Técnicas, Argentina

\section{EXPERIMENTAL}

The workıng electrodes were made from $999 \%$ purity electrolytic polycrystalline $\mathrm{Cu}$ rods Each specimen was machined in the lathe from drawn $\mathrm{Cu}$ bars of $1 / 4$ inch diameter to obtain cylindrical specimens The actual workıng electrode active area was the base of a small $\mathrm{Cu}$ cylinder of $03 \mathrm{~cm}$ diameter which was mounted as a horizontal disc electrode in contact with a hanging electrolyte column[20] by fixing the height of the meniscus to $5 \mathrm{~mm}$ from the solution level This arrangement could be used under either a stagnant solution condition or with stirring up to $5000 \mathrm{rpm}$ Each workıng electrode was firstly mechanically polished, then thermally treated, and finally, subjected to electropolishing

The mechanical treatment comprised a sequential polishing with different grain size emery papers up to $1 \mu \mathrm{m}$ gnt diamond paste The specimens were then repeatedly rinsed with distilled water, and finally dried in air

To assure good reproducibility of results annealed $\mathrm{Cu}$ specimens were used Therefore, the specimens were annealed at $500^{\circ} \mathrm{C}$ for $2 \mathrm{~h}[21]$ to eliminate residual mechanical stresses and to produce a relatively more uniform grain distribution in the metal. For this purpose a number of $\mathrm{Cu}$ specimens were lodged in a Pyrex tube which was repeatedly swept with Ar using a vacuum line, and then sealed off with a residual Ar pressure of about 1-2 Torr The heating and cooling rates employed for annealing were $500^{\circ} \mathrm{C} \mathrm{h}^{-1}$, and $80-100^{\circ} \mathrm{Ch}^{-1}$, respectively

The electropolishing of annealed $\mathrm{Cu}$ specimens was made in stagnant ortho-phosphonc acid (1 $71 \mathrm{~g} \mathrm{~cm}^{-3}$ ) at $03 \mathrm{~A} \mathrm{~cm}^{-2}$ and room temperature 
In this case a large $\mathrm{Cu}$ plate counter electrode parallel to the small $\mathrm{Cu}$ disc electrode surface was employed to achieve a reasonably good primary current distribution in the cell The electropolishing time was varied from 5 to $10 \mathrm{~min}$

Finally, the treated $\mathrm{Cu}$ specimens were rinsed repeatedly with twice-distilled water The surface finishing was checked by reflection and scanning electron microscopies

Electrochemical runs were made in a conventional three-electrode Pyrex glass cell The counter electrode was a large area Pt screen placed around the working electrode The reference electrode was a saturated sodium chlonde/calomel electrode (ssce) The latter was connected to the cell through a conventional Luggin capillary arrangement filled with the electrolyte solution Runs were made at $250 \pm 01^{\circ} \mathrm{C}$ in the following electrolyte solutions (1) $x \mathrm{M} \mathrm{Na} \mathrm{NPO}_{4}+$ y $\mathrm{M} \mathrm{NaH}_{2} \mathrm{PO}_{4}$ to be adjusted to either pH 60 or 80 , (11) $005 \mathrm{M} \mathrm{Na} \mathrm{NPO}_{4}+01 \mathrm{M} \mathrm{NaOH}$ at $\mathrm{pH} 115$ Solutions were prepared from twice-distilled water and A R chemicals, and purged in the cell with purified Ar for $1 \mathrm{~h}$ prior to each run

Preceding each run the working electrode was firstly potential cycled at $001 \mathrm{~V} \mathrm{~s}^{-1}$ between the hydrogen evolution reaction potential range to the $\mathrm{Cu}$ passivation potential range to obtain a reproducible voltammogram Cyclic voltammograms were recorded at $001 \mathrm{~V} \mathrm{~s}^{-1}$ between preset cathodic $\left(E_{\mathrm{s}, \mathrm{c}}\right)$ and anodic $\left(E_{\mathrm{s}, \mathrm{a}}\right)$ switching potentials and plotted by takıng $J$, the current density referred to $A$, the geometric workıng electrode area, $v s E$, the applied potential Anodic current transients were presented as $j$ vs time $(t)$ plots in the phosphate buffers at a constant potential $E_{\mathrm{s}}$ In these cases, the working electrode has been previously held at the potential $E_{\mathrm{c}}$ for $3 \min \left(E_{\mathrm{c}}<E_{\mathrm{s}}\right)$, a potential which is close to the HER threshold potential

SEM observations and EDAX of the electrochemically treated and blank specimens were made by using a Cambridge Stereoscan 150

\section{RESULTS}

\section{Voltammetric data}

311 Phosphate buffer, $p H 6$ The stabilized voltammogram of $\mathrm{Cu}$ specimens in this buffer solution was recorded at $001 \mathrm{~V} \mathrm{~s}^{-1}$ between $E_{\mathrm{s}, \mathrm{c}}=-065 \mathrm{~V}$ and $E_{\mathrm{s}, \mathrm{a}}=010 \mathrm{~V}$ (F1g 1a) The positive potential going scan shows an anodic current starting at $\mathrm{ca}-02 \mathrm{~V}$ which defines a broad anodic current peak (peak $I_{a}$ ) at $-002 \mathrm{~V}$ The anodic charge density $\left(q_{B}\right)$ involved in peak $I_{a}$ is $39 \mathrm{mC} \mathrm{cm}^{-2}$ The returning scan exhibits a single sharp cathodic peak (peak $I_{c}$ ) at $-013 \mathrm{~V}$ with a small hump at its descending branch The cathodic charge density $\left(q_{c}\right)$ corresponding to peak $I_{c}$ is $26 \mathrm{mC} \mathrm{cm}^{-2}$

The cyclovoltammograms show that the peak potential difference of peaks $I_{a} / I_{c}$ decreases as $E_{2,0}$ is stepwise changed from -045 to $010 \mathrm{~V}$, and simultaneously the cathodic hump disappears The fact that in the present case $q_{\mathrm{a}}>q_{\mathrm{c}}$ suggests that the electroformation of the anodic layer is presumably accompanied by the formation of soluble $\mathrm{Cu}^{2+}$ species during the electrooxidation scan
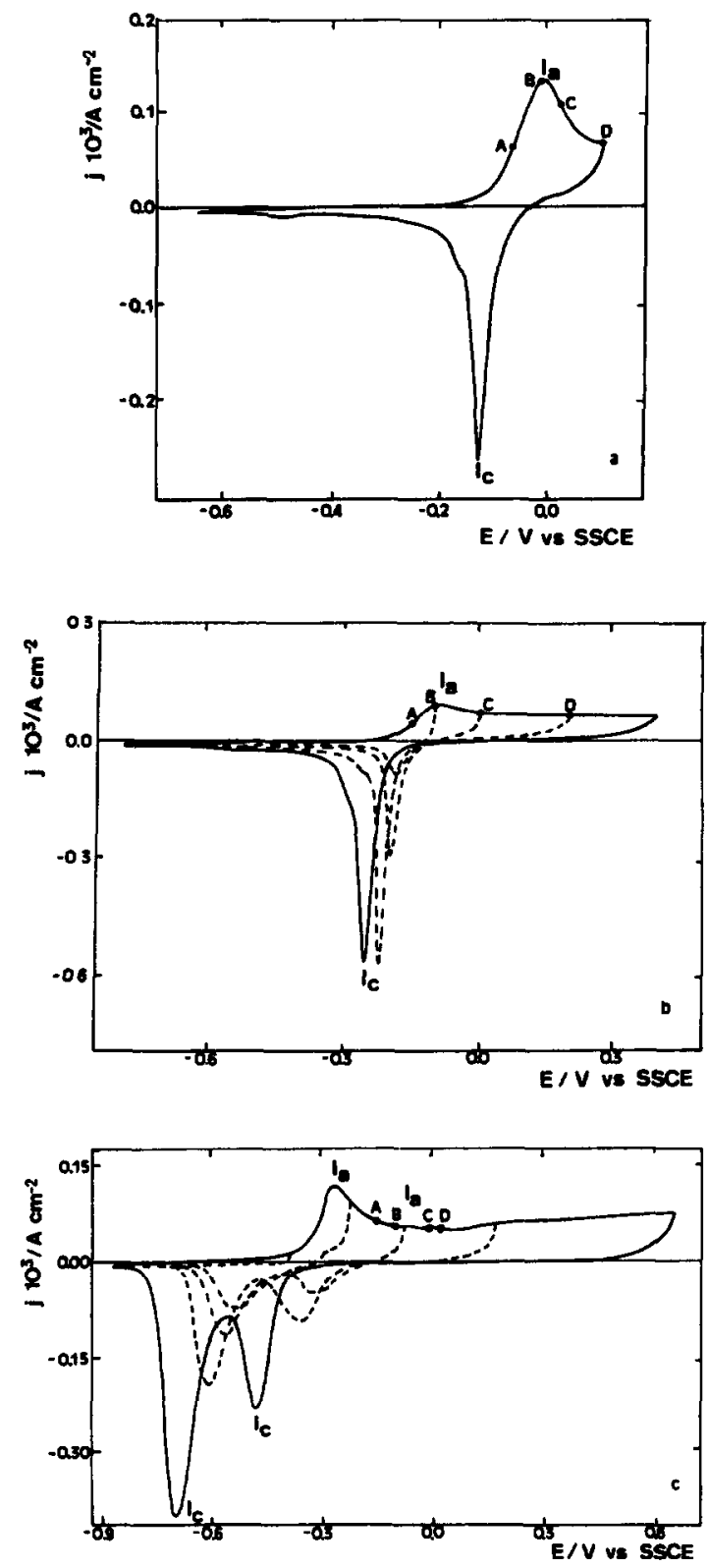

Fig 1 Voltammograms of annealed $\mathrm{Cu}$ electrodes in phosphate buffer solutions run at $001 \mathrm{Vs}^{-1}$, (a) $\mathrm{pH} \mathrm{6,} \mathrm{(b)} \mathrm{pH} 8$ and (c) pH 115 Points labelled $A, B, C$ and D correspond to potential values at which the potentiostatic current transients were recorded

For peak $I_{a}$, the peak current, $t_{p}$, vs $v^{1 / 2}$ plot, approaches, in principle, two linear regions with a cross over at $v=002 \mathrm{Vs}^{-1}$ (Fig 2) suggesting that there are two diffusion controlled processes operating on different time scales

Finally, the voltammogram also shows a very broad although small cathodıc peak covering -045 to $-050 \mathrm{~V}$

312 Phosphate buffer, $\mathrm{pH} 8$ The stabilized voltammogram of a $\mathrm{Cu}$ specimen in this solution run at $001 \mathrm{~V} \mathrm{~s}^{-1}$ between $E_{8, c}=-080 \mathrm{~V}$ and $E_{\mathrm{s}, \mathrm{a}}=040 \mathrm{~V}$ is shown in Fig $1 \mathrm{~b}$ The positive potential going scan presents peaks $I_{a}$ and $I_{c}$ at -010 and 


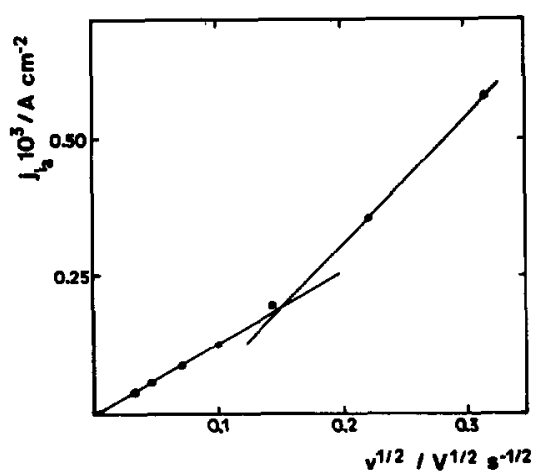

Fig 2 Current peak height $\rho_{\ln }$ os $v^{1 / 2}$ relationship in phosphate buffer at pH 6

$-025 \mathrm{~V}$, respectively When $E_{\mathrm{s}, \mathrm{a}}$ is set in the -045 to $040 \mathrm{~V}$ range, peak $I_{c}$ looks very sharp. Likewise, an anodic current plateau extending from $005 \mathrm{~V}$ upwards can be observed In this case the anodic to cathodic charge density ratio approaches a value close to one $\left(q_{\mathrm{a}}=118 \mathrm{mC} \mathrm{cm}^{-2}, q_{\mathrm{c}}=117 \mathrm{mC} \mathrm{cm}^{-2}\right)$ Nevertheless, the overall voltammetric charge decreases as the rotation speed $(\omega)$ of the working electrode is increased gradually from 0 to $3500 \mathrm{rpm}$, although one can note that the cathodic voltammetric charge decreases faster than the anodic one The latter is an indication that the entire electrochemical process involves a transport of soluble species related to the anodic reaction

The same minor contributions referred to in Section 311 are also seen in the voltammogram depicted in Fig lb

313 Phosphate buffer, $p H 115$ The stabilized voltammogram of a $\mathrm{Cu}$ specimen in this buffer solution was run at $001 \mathrm{Vs}^{-1}$ between $E_{\mathrm{s}, \mathrm{c}}=$ $-086 \mathrm{~V}$ and $E_{\mathrm{sa}}=065 \mathrm{~V}$ (Fig $\left.1 \mathrm{lc}\right)$ The positive going scan exhibits a broad peak $I_{a}^{\prime}$ located at $-028 \mathrm{~V}$, and at more positive potentials, a nearly constant anodic current Likewise, the negative potential going scan shows the cathodic current peaks $I_{c}$ and $I_{c}^{\prime}$ at -049 and $-070 \mathrm{~V}$, respectively The voltammograms run between $E_{\mathrm{s}, \mathrm{c}}=-086 \mathrm{~V}$ and a value of $E_{\mathrm{s}, \mathrm{a}}$ progressively shifted in the positive direction reveal that the initial part of peak $\mathbf{I}_{2}^{\prime}$ is related to peak $I_{c}^{\prime}$, whereas the positive potential branch of the peak $I_{a}^{\prime}$ as well as the constant anodic current region appear to be related to both peaks $I_{c}$ and $I_{c}^{\prime}$ These results are similar to those prevously reported for $\mathrm{Cu}$ in alkalıne solutions[22] From the latter it was concluded that a thin $\mathrm{Cu}(\mathrm{I})$ oxide was initially formed at lower potentials, and subsequently a hydrous $\mathrm{Cu}(\mathrm{II})$ oxide layer was produced at more positive potentials Thus, at $\mathrm{pH} 115$ the initial part of peak $\mathrm{I}_{\mathrm{a}}$ can be assigned to the electroformation of a $\mathrm{Cu}(\mathrm{I})$ oxide layer which can be electroreduced to $\mathrm{Cu}$ in the potential range of peak $I_{c}^{\prime}$

On the other hand, the positive potential branch of peak $\mathrm{I}_{\mathrm{a}}^{\prime}$ as well as the constant anodic current region can be associated with the electroformation of a hydrous $\mathrm{Cu}$ (II) oxide layer which is electroreduced to $\mathrm{Cu}(\mathrm{I})$ oxide in the potential range of peak $\mathrm{I}_{c}$. It can be noted that under comparable conditions with respect to $\mathrm{pH} 6$ and 8 , the following values result $q_{\mathrm{a}}=1.1 \mathrm{mC} \mathrm{cm}^{-2}, \quad q_{\mathrm{a}}^{\prime}=1.5 \mathrm{mC} \mathrm{cm}^{-2}$ and $q_{\mathrm{c}}=10 \mathrm{mC} \mathrm{cm}^{-2}$ and $q_{\mathrm{c}}^{\prime}=15 \mathrm{mC} \mathrm{cm}^{-2}$

\subsection{Anodic current transients in phosphate buffers at different $\mathrm{pH}$}

In the phosphate buffer at pH 6 the anodic current transients at constant potential were run by stepping the potentral to $E_{\mathrm{c}}=-035 \mathrm{~V}$ for $3 \mathrm{~min}$ to attain the complete electroreduction of the $\mathrm{Cu}$ surface, and subsequently to $E$, to record the corresponding current transient For values of $E_{\mathrm{a}}$ ranging between -007 and $010 \mathrm{~V}$ the current transients exhibit only a monotonous decay to reach the corresponding stationary passivity current value without other particular features (Fig 3a) The $t$ vs $t^{-1 / 2}$ plots at low $E$, values give straight lines for $t>05 \mathrm{~s}$ with a slope dependent on $E_{\mathrm{s}}\left(\mathrm{F}_{1 \mathrm{~g}} \mathrm{4}\right)$

Similar anodic current transients resulted at $\mathbf{p H} 8$ and 115 (Fig $3 b$ and c) In these cases the values of
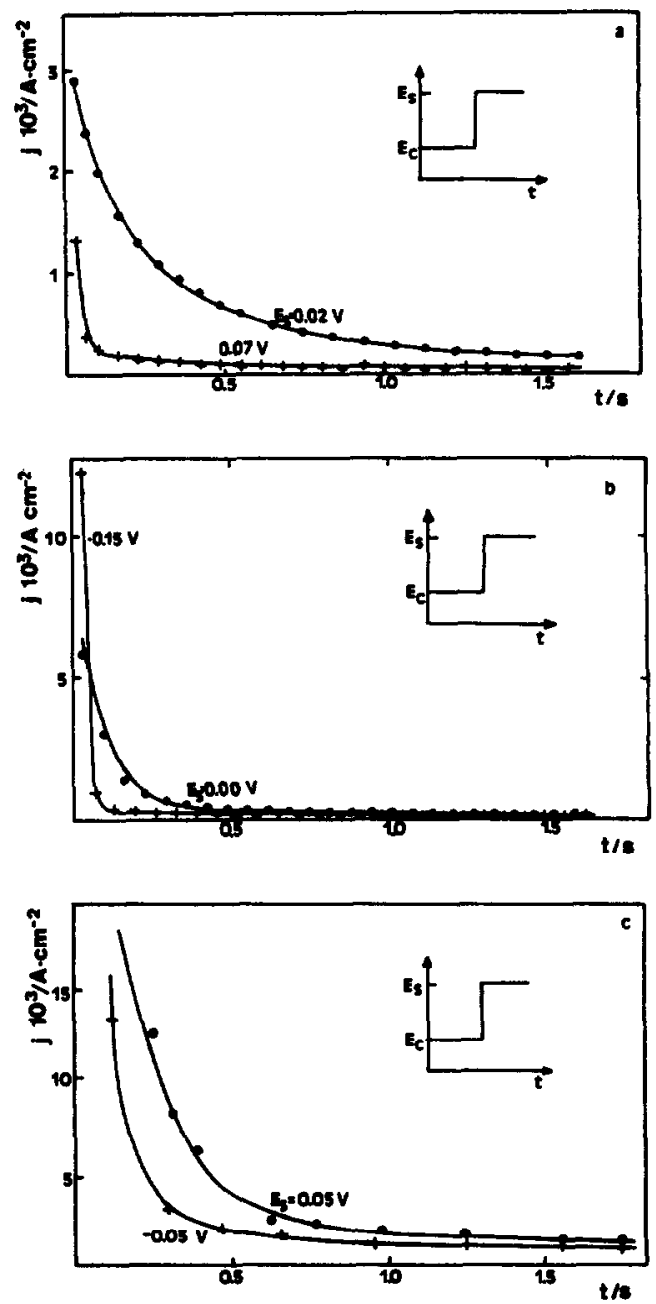

Fig. 3 Potentiostatic current transients for Cu electrodes in phosphate buffer, (a) pH 6, (b) pH 8 and (c) pH 115 The values of $E_{4}$ are indicated in the figures The full trace corresponds to the theoretical function calculated from equations (12) and (13) 


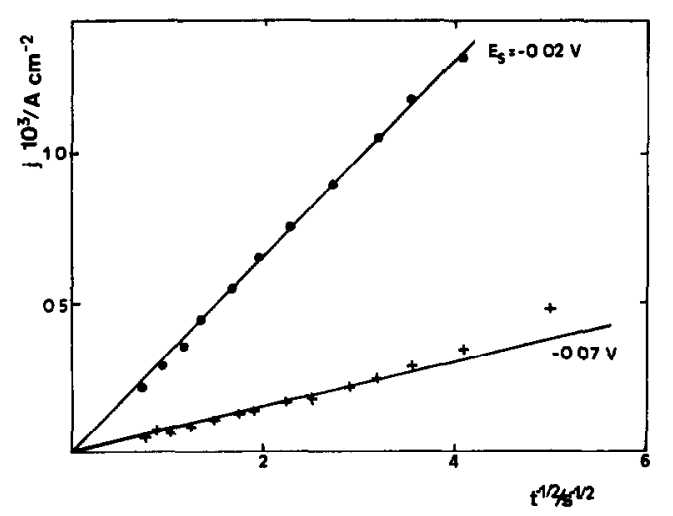

Fig 4 Transient current density $J$ os $t^{-1 / 2}$ plots at pH 6

$E_{\mathrm{c}}$ and $E_{\mathrm{s}}$ were conveniently adjusted, as shown in the corresponding figures

\section{SEM micrographs and EDAX data}

SEM micrographs were obtained at 400,40 and $2 \mu \mathrm{m}$ unit scale, for blank and electrochemically treated specimens The latter were held for $10 \mathrm{~min}$ at different potentials, namely, $-080,-045$ or $-015 \mathrm{~V}$ in the solution at $\mathrm{pH} 115,-080$, -020 or $015 \mathrm{~V}$ in the solution at $\mathrm{pH} 8,-075$, -010 or $015 \mathrm{~V}$ in the solution at pH 6

The SEM micrographs of the blank exhibit at the $400 \mu \mathrm{m}$ unit scale (Fig 5a) rounded grains which at a larger magnification ( $F_{1} g 5 b$ ) present rounded micropits A detalled micrograph of one of these micropits (Fig 5c) which have been formed during $\mathrm{Cu}$ electropolishing, show a rounded morphology

The SEM micrographs of the $\mathrm{Cu}$ specimens anodized at $-015 \mathrm{~V}$ and $\mathrm{pH} 115$ (F1g 6) show a $\mathrm{Cu}$ surface similar to that seen for the blank ( $F_{1} g$ 5)

The same results are found for $\mathrm{Cu}$ specimens treated at $\mathrm{pH} 6$ and 8 and anodized to -080 and $-020 \mathrm{~V}$ In contrast, for those specimens anodized at $015 \mathrm{~V}$, the formation of a thin crystalline anodic layer can be seen at the highest magnification (F1g 7) This crystalline layer appears on the $\mathrm{Cu}$ specimens subjected to high positive anodization potentials at low $\mathrm{pH}$

The EDAX covered different domains of the specimen surface including micropits For those electrodes anodized at potentials lower than the potential of peak $I_{a}$, the EDAX of the main surface domains indicates the major contribution of $\mathrm{Cu}$, minor traces of $\mathrm{Al}$ and $\mathrm{Si}$ (Fig 8a) But for those specimens anodized at potentials more positive than the potential of peak $\mathrm{I}_{\mathrm{a}}$ and low $\mathrm{pH}$, the EDAX revealed the presence of $P$ on the surface (Fig $8 b$ )

On the other hand, the EDAX data inside the micropits reveals two interesting features Firstly, independently of the anodization conditions, all specimens show a relatively large concentration of $A l$ and Si inside the pits Secondly, the EDAX data show no $P$ signal inside the micropits, except for those specimens which were anodized at high positive potential and low $\mathrm{pH}$, although in these cases, the amount of $P$ was just within the limits of detection

\section{DISCUSSION}

\section{Preliminary considerations}

The electrochemical behaviour of polycrystallıne $\mathrm{Cu}$ in aqueous solutions containing phosphate tons is rather complex as it involves at least two main processes, namely, the formation of soluble species and the onset of passivity caused by the growth of an anodic film both processes being $\mathrm{pH}$ dependent This conclusion is derived from the values of $q_{\mathrm{a}}$ and $q_{\mathrm{c}}$, the voltammetric charges resulting from peaks $I_{a}$ and $I_{c}$, respectıvely The value of $q_{\mathrm{a}}$ particularly under stırring, is greater than the value of $q_{c}$, the difference $\Delta q=q_{\mathrm{a}}-q_{\mathrm{c}}$ becomes smaller as the solution $\mathrm{pH}$ is shifted from 6 to 115 This result indicates that the formation of soluble species decreases considerably as the solution $\mathrm{pH}$ increases

For interpreting the experimental data it is convenient to consider the following equilibria under standard conditions $[23,24]$

$$
\begin{gathered}
\mathrm{Cu}^{+}+\mathrm{e}^{-}=\mathrm{Cu}, \quad E^{\circ}=052 \mathrm{~V} \quad \text { (nhe) } \\
\mathrm{Cu}^{2+}+\mathrm{e}^{-}=\mathrm{Cu}^{+}, \quad E^{\circ}=016 \mathrm{~V} \\
\mathrm{Cu}^{2+}+2 \mathrm{e}^{-}=\mathrm{Cu}, \quad E^{\circ}=034 \mathrm{~V} \\
\mathrm{Cu}^{2+}+\mathrm{H}_{2} \mathrm{O}=\mathrm{CuOH}^{+}+\mathrm{H}^{+}, \quad \mathrm{p} K_{\mathrm{a}}=73 \\
2 \mathrm{Cu}^{2+}+\mathrm{H}_{2} \mathrm{O}=\mathrm{Cu}_{2} \mathrm{O}^{2-}+2 \mathrm{H}^{+}, \quad \mathrm{p} K_{\mathrm{a}}=105 \\
\mathrm{Cu}^{+}+\mathrm{OH}^{-}=\mathrm{CuOH}, \mathrm{p} K_{\mathrm{s}}=147 \\
\mathrm{Cu}^{2+}+2 \mathrm{OH}^{-}=\mathrm{Cu}(\mathrm{OH})_{2}, \quad \mathrm{p} K_{\mathrm{s}}=199 \\
2 \mathrm{PO}_{4}^{3-}+3 \mathrm{Cu}^{2+}=\mathrm{Cu}_{3}\left(\mathrm{PO}_{4}\right)_{2}, \quad \mathrm{p} K_{\mathrm{s}}=369 \\
\mathrm{H}_{3} \mathrm{PO}_{4}=\mathrm{H}^{+}+\mathrm{H}_{2} \mathrm{PO}_{4}^{-}, \quad \mathrm{p} K_{1 \mathrm{a}}=21 \\
\mathrm{H}_{2} \mathrm{PO}_{4}^{-}=\mathrm{H}^{+}+\mathrm{HPO}_{4}^{2-}, \quad \mathrm{p} K_{2 \mathrm{a}}=72 \\
\mathrm{HPO}_{4}^{2-}=\mathrm{H}^{+}+\mathrm{PO}_{4}^{3-}, \quad \mathrm{p} K_{3 \mathrm{a}}=127
\end{gathered}
$$

According to the potential and $\mathrm{p} K$ values of these reactions the composition of the anodic layer should depend on the phosphate concentration and solution pH Thus, at pH 6-8 basic $\mathrm{Cu}$ phosphates should be the main component of the passive layer These type of compounds are well known, covering a wide range of phosphate/hydroxide stoichiometries[24] This conclusion is consistent with EDAX data showing the presence of $\mathrm{P}$ on the surface of $\mathrm{Cu}$ specimens anodized at those $\mathrm{pH}\left(\mathrm{F}_{1 \mathrm{~g}} \mathrm{8b}\right.$ ) The formation of this type of layers explains the single voltammetric electroreduction peak observed for $\mathrm{Cu}$ in phosphate buffer at $\mathrm{pH}$ 6-8

On the other hand, at $\mathrm{pH} 115$, the characteristics of reactions (1)-(9) also indicate that the composition of the passive layer should change in the direction of increasing the contribution of $\mathrm{Cu}$ oxide and hydroxide species despite the fact that the phosphate ions are present in the solution Accordingly, the voltammetnc behaviour of $\mathrm{Cu}$ actually reproduces that already described for $\mathrm{Cu}$ in plain alkaline solution[25], $v$ the composition of the passive layer can be described as a $\mathrm{Cu}$ (I) oxide/hydrous $\mathrm{Cu}$ (II) oxide duplex layer structure 

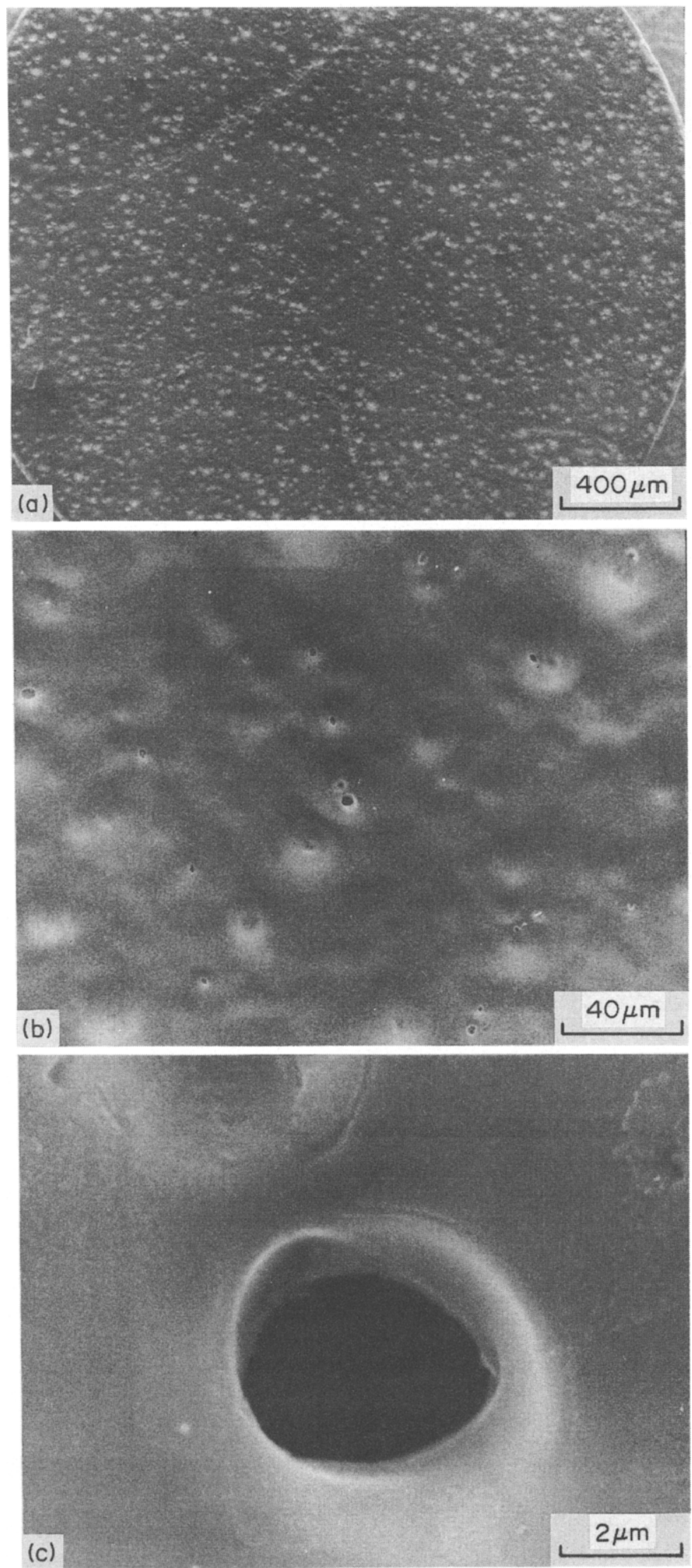

Fig 5 SEM micrographs of the Cu blank specimens obtained at different magnifications Bars correspond to $400 \mu \mathrm{m}$ (a), $40 \mu \mathrm{m}$ (b), and $2 \mu \mathrm{m}$ (c) 

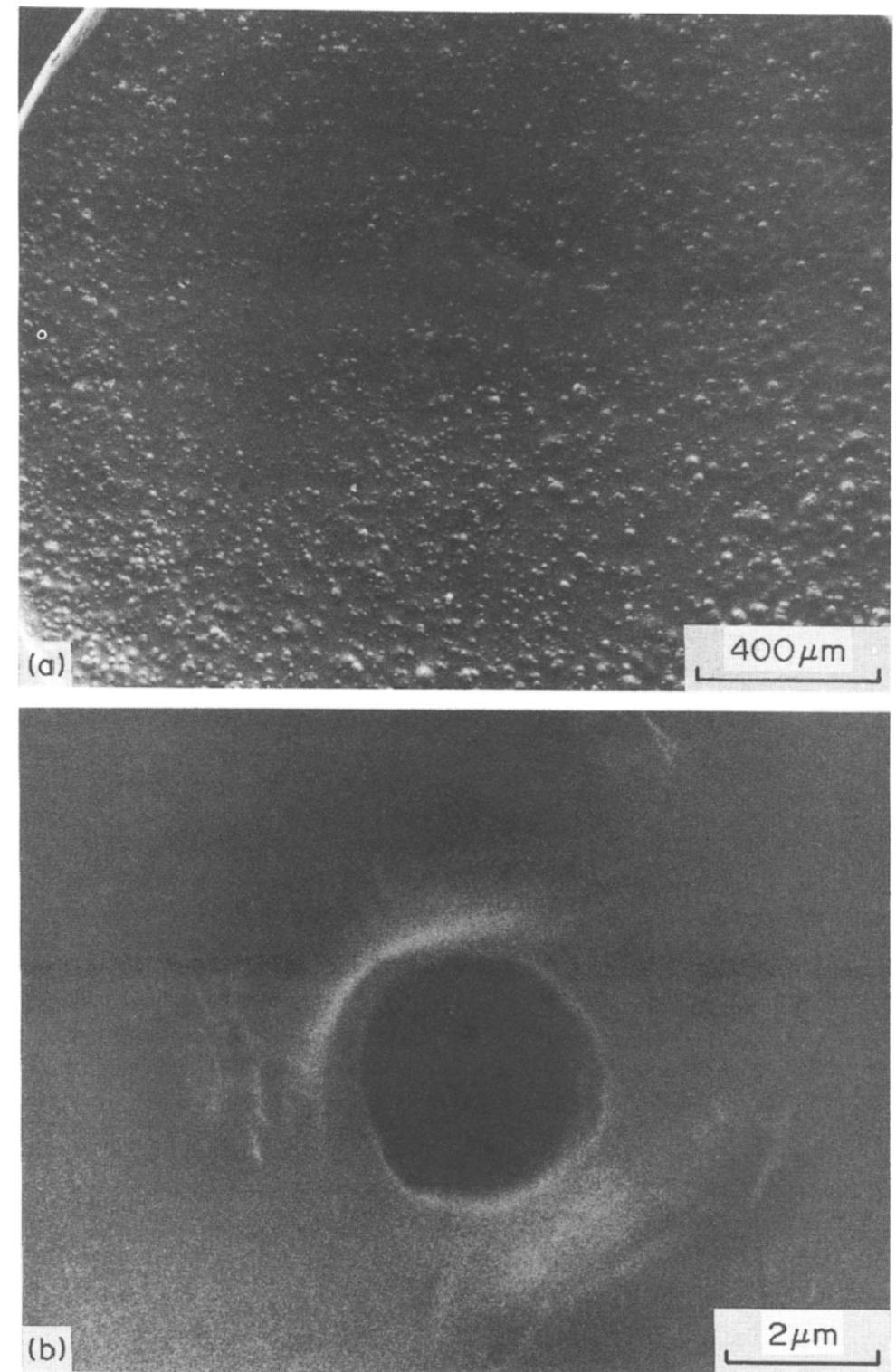

Fig 6 SEM micrographs at different magnifications of a $\mathrm{Cu}$ specimen anodized in the phosphate buffer, pH $115, E_{3}=-015 \mathrm{~V}$ Bars correspond to (a) $400 \mu \mathrm{m}$ and (b) $2 \mu \mathrm{m}$,

\section{Analysis of the anodic current transtents}

The analysis of the anodic current transients obtained at constant potential offers the possibility of modelling the entire electrodissolution and passivation of $\mathrm{Cu}$ in the different phosphate containing solutions For this purpose, the model previously described for the passivity of $\mathrm{Cu}$ and other metals in alkaline solutions[26-28] can be used, due to the fact that the behaviour of the system at the highest $\mathrm{pH}$ resembles that already described for $\mathrm{Cu}$ in alkaline solutions Thus, the overall anodic current density, $J_{t}$, was expressed as the sum of three main contributions, namely, $J_{\mathrm{dl}}$, the current density associated with the double layer charging, $J_{a}$, the current density related to $\mathrm{Cu}$ electrodissolution, and $j_{\mathrm{p}}$, the current density related to the passive layer formation Thus

$$
J_{\mathrm{t}}=J_{\mathrm{dl}}+J_{\mathrm{a}}+\jmath_{\mathrm{p}}
$$

Under the present conditions, the contribution of $J_{\mathrm{dl}}$ can be neglected because it disappears in a time range much shorter than that of other transient processes Accordingly, equation (10) can be written as

$$
\jmath_{\mathrm{t}}=\jmath_{\mathrm{a}}+\jmath_{\mathrm{p}}
$$

Hence, as a first approach one can describe the growth of the anodic layer as an instantaneous nucleation and 2D growth under diffusion control The corresponding rate equation is[29]

$$
J_{\mathrm{p}}=P_{1} \exp \left(-P_{2} t\right),
$$

where

$$
\begin{aligned}
P_{1} & =q \pi K D N_{0} \\
P_{2} & =\pi K D N_{0} \\
P_{1} / P_{2} & =q
\end{aligned}
$$




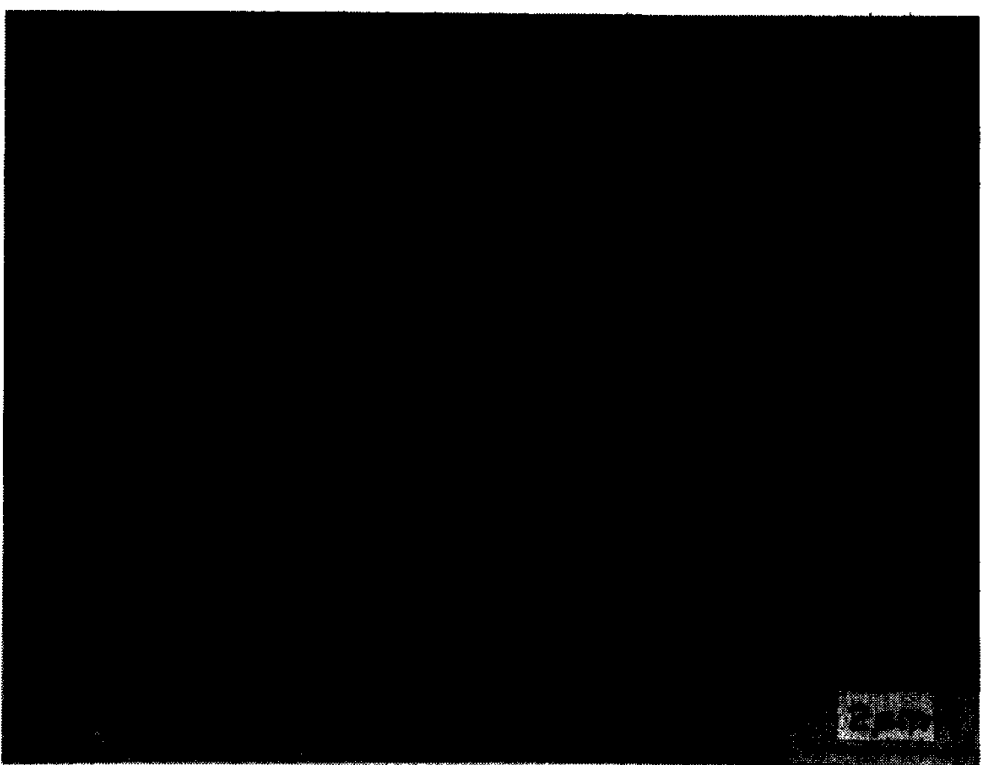

Fig 7 SEM micrograph of a $\mathrm{Cu}$ specimen anodized a pH 6 and $E_{\mathrm{s}}=015 \mathrm{~V}$ Bar corresponds to $2 \mu \mathrm{m}$
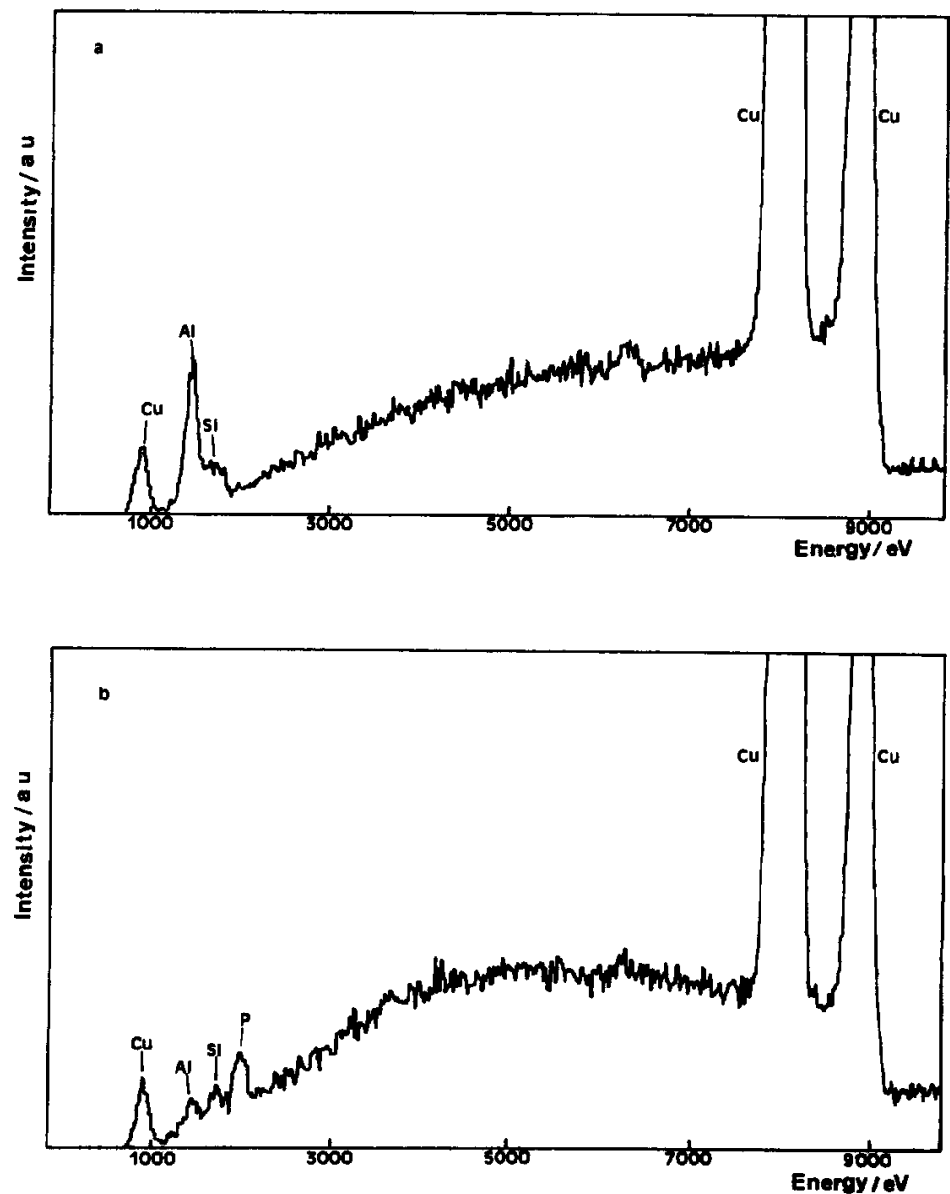

Fig 8 EDAX of Cu specimens anodized at different potentials (a) $E_{\text {s }}$ more negative than the threshold potential of peak $I_{a}$, (b) $E_{s}$ more positive than the threshold potential of peak $I_{a}$ 
Table 1 Parameters used in simulation of potentiostatic current transients with equations (12) and (13)

\begin{tabular}{|c|c|c|c|}
\hline$E_{\mathbf{a}} / \mathrm{V}$ & $P_{1} / P_{2} / 10^{6} \mathrm{C} \mathrm{cm}^{-2}$ & $P_{3} / 10^{4} \mathrm{As}^{1 / 2} \mathrm{~cm}^{-2}$ & $P_{4} / \mathrm{s}^{-1}$ \\
\hline \multicolumn{4}{|c|}{$\mathrm{pH} 6$} \\
\hline $\begin{array}{r}-007 \\
-002 \\
110 \\
010\end{array}$ & $\begin{array}{c}941 \\
48 \\
110 \\
599\end{array}$ & $\begin{array}{l}038 \\
171 \\
329 \\
319\end{array}$ & $\begin{array}{lll}0 & 132 \\
0 & 02 \\
0 & 014 \\
0 & 003\end{array}$ \\
\hline \multicolumn{4}{|c|}{ pH 8} \\
\hline $\begin{array}{r}-015 \\
-010 \\
000 \\
020\end{array}$ & $\begin{array}{l}121 \\
715 \\
267 \\
419\end{array}$ & $\begin{array}{l}0096 \\
0831 \\
248 \\
142\end{array}$ & $\begin{array}{ll}0 & 199 \\
0 & 078 \\
0 & 053 \\
0 & 040\end{array}$ \\
\hline \multicolumn{4}{|c|}{ pH 115} \\
\hline $\begin{array}{r}-015 \\
-010 \\
000 \\
020\end{array}$ & $\begin{array}{l}163 \\
284 \\
451 \\
614\end{array}$ & $\begin{array}{l}062 \\
130 \\
138 \\
181\end{array}$ & $\begin{array}{r}155 \\
1225 \\
656 \\
566\end{array}$ \\
\hline
\end{tabular}

$q$ is the charge density involved in the passive layer formation, $K$ is a proportionality constant, $D$ is the diffusion coefficient of the species involved in the passive layer growth, and $N_{0}$ is the number of sites available for nucleation

On the other hand, one can attempt to model the proper $\mathrm{Cu}$ electrodissolution as a nucleation and growth of 3D voids at certain sites of the metal surface under diffusion control For an instantaneous nucleation[30], the corresponding rate equation is

where

$$
\begin{aligned}
& J_{\mathrm{a}}=\left(P_{3} / t^{1 / 2}\right)\left[1-\exp \left(-P_{4} t\right)\right], \\
& P_{3}=z F D^{\prime 1 / 2} \Delta c^{\prime} \pi^{-1 / 2} \\
& P_{4}=\pi K^{\prime} D^{\prime} N_{0}^{\prime},
\end{aligned}
$$

and the dashed symbols have the same meaning as before, except that now they refer to the conditions of the new model, and $\Delta c^{\prime}$ is the concentration gradient created by the actual $\mathrm{Cu}$ electrodissolution process The presence of two different diffusional processes, in the short time range and in the long time range, respectively, is supported by the two linear portions shown in the $t_{\mathrm{p}} v s v^{1 / 2}$ relationship (Fig 2)

By using equations (11)-(13) the current transients recorded at different stages of $\mathrm{Cu}$ electrodissolution and passivation at $\mathrm{pH}$ 6-115 (Fig $3 \mathrm{a}-\mathrm{c}$ ) can be

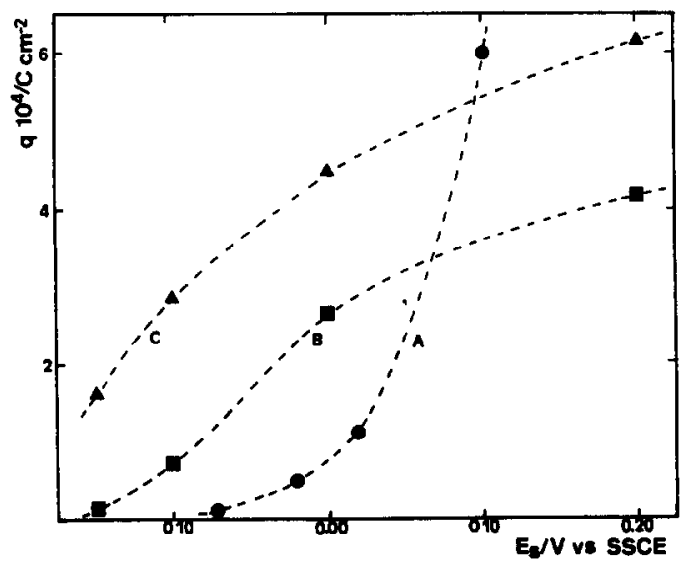

Fig 9 Dependence of $q$ on $E_{\mathrm{s}}$ (A) $\mathrm{pH} \mathrm{6,} \mathrm{(B)} \mathrm{pH} 8$, (C) $\mathrm{pH} 115$ reproduced with the set of parameters assembled in Table 1 These parameters contain valuable information on the processes under investigation The values of $q, P_{3}$ and $P_{4}$ corresponding to the potentual values indicated by points $A, B, C$ and $D$ in the voltammograms shown in Fig 1 are shown in Table 1 At $\mathrm{pH}$ 6-8 the value of $q$ becomes smaller than the single monolayer charge density value for points $A, B$, and $C$ of the current peak $I_{2}$ (Fig 9) However, $q$ reaches the monolayer charge density value at point $D$, which rests in the net passive region On the other hand, at pH 115 the value of $q$ reaches the monolayer charge density value already at point $C$ in the voltammogram (Fig lc)

At a constant $\mathrm{pH}$ the decrease of $P_{4}$ reflects the change of $N_{0}^{\prime}$ with $q$ according to the coverage and thickness of the passive layer Moreover, the fact that the micropit size does not change during the anodization allows us to discard the possibility that the sites for $\mathrm{Cu}$ electrodissolution could be identified with the micropits formed during the $\mathrm{Cu}$ electropolishing This conclusion emerges from the analysis of the SEM data

On the other hand, the potential dependence of $P_{3}$ reflects the influence of the potential on $\Delta c^{\prime}$ and $D^{\prime}$ At potentials where the passivating layer is still incomplete, the value of $\Delta c^{\prime}$ increase with the potential and the diffusion coefficient of $\mathrm{Cu}^{2+}$ ion in aqueous solutions should be considered Consequently, under these conditions the value of $P_{3}$ should increase the applied potential Conversely, at potentuals where the passivatıng layer approaches completeness the main influence on $P_{3}$ comes out from the diffusion coefficient of $\mathrm{Cu}^{2+}$ ions through the passivatıng layer which should be smaller than the former one This implies that $P_{3}$ firstly increases rather sharply and later slightly decreases or remains nearly constant with the applied potential

At a constant potential the change of $\mathrm{pH}$ from 6 to 115 results in an increase of $q$ as it should correspond for a gradual thickening of the inner passive layer Accordingly, at high positive potentials a decrease of $P_{3} 15$ observed This fact agrees with the decrease observed in both $q_{\mathrm{a}}$ and $q_{\mathrm{c}}$ as the $\mathrm{pH}$ increases The high values of $P_{3}$ obtained at $\mathrm{pH} 115$ can be associated with an increase of the $N_{0}^{\prime}$ value, probably due to the change in the chemical 
composition of the inner passive layer from $\mathrm{Cu}$ (II) phosphate (pH 6-8) to a complex $\mathrm{Cu}(\mathrm{I})-\mathrm{Cu}(\mathrm{II})-$ oxıde-phosphate layer (pH 115 )

From the physical picture of the proposed model, one should expect that at the beginning of $\mathrm{Cu}$ passivation the electrodissolution of the metal takes place mostly at the predominant passive layer-free areas. In this case, the passivating layer can be described as a number of thin islands coverng only a small fraction of the total metal surface, the formation of these areas being initially relatively faster than the reaction producing soluble $\mathrm{Cu}$ species The formation of island-type structures has been recently demonstrated by in situ scanning tunneling microscopy for the electrochemical growth of the Au oxide layer on $\mathrm{Au}[31]$

Otherwise, at the peak potential one should expect that about one half of the surface becomes already covered by islands of passivating species Then, the electrodissolution of $\mathrm{Cu}$ can occur etther via the free metal surface or via the passivating layer covered area, although in this case the latter contribution may be considerably smaller than the first one

Finally, when the formation of the passive layer is complete, the electrodissolution of $\mathrm{Cu}$ should proceed only through the passivating layer and the electroformed $\mathrm{Cu}^{2+}$ soluble species can precipitate at the outer region of the passivating layer (layer thickening) This explanation is consistent with the relatively large values of $q_{\mathrm{c}}$ as compared to the value of $q$ derived from the current transients because the former one involves the electroreduction of both the inner and the outer parts of the passivating layer

Hence, the precedent mechanistic model describes satisfactorily the kinetics of the complex processes related to the electrodissolution and passivation of $\mathrm{Cu}$ in phosphate containing solutions at $\mathrm{pH}$ 60-11 5 for different stages of $\mathrm{Cu}$ passivation

Acknowledgements-Financial support for this work by the Gobierno de Cananas (Dirección General de Universidades e Investigación) under contract No 46/01 0688 , is gratefully acknowledged Authors thank Prof S Trasattı and $\mathrm{Mr}$ G Terzaghi, Centro de Microscopia Elettronica del Departamento de Chimica Fisica ed Elettrochimica dell'Università di Milano for making available SEM and EDAX facilities

\section{REFERENCES}

1 T P Hoar and G P Rothwell, Electrochum Acta 9, 135 (1964)

2 T P Hoar and T W Farthing, Nature 169, 324 (1952)

3 M C Petıt, Electrochim Acta 8, 217 (1963)
4 B Pointu, Electrochim Acta 14, 1207 (1969)

5 B Pointu, Electrochum Acta 14, 1213 (1969).

6 P Poncet, M Brazzaz, B Pointu and J Rousseau, J Chum Phys 75, 287 (1978)

7 G H Sedahmed, M Z El-Abd, I A S Mansour, A M Ahmed and A A Wragg, J appl Electrochem 9, 1 (1979)

$8 \mathrm{~K}$ Kojıma and C W Tobıas, $J$ electrochem Soc 120 , 1026 (1973)

9 J A Allen, Trans Faraday Soc 48, 273 (1952)

10 E C Willams and M A Barrett, $J$ electrochem Soc 103, 363 (1956)

11 M Novak and A Szucs, $J$ electroanal Chem 210, 237 (1986)

$12 \mathrm{M}$ Novak, A $\mathrm{K}$ Reddy and $\mathrm{H}$ Wroblowa, $J$ electrochem Soc 117, 733 (1970)

$13 \mathrm{~K}$ Ohash, T. Murakawa and S Nagaura, $J$ electrochem Soc Jpn 30, 165 (1962)

14 K Kojıma and C W Tobras, $J$ electrochem Soc 120, 1202 (1973)

15 M Novak and A Szucs, $J$ electroanal Chem 210, 229 (1986)

16 B Pointu, M Brazaz, P Poncet, J Rousseau and N Muhlstein, $J$ electroanal Chem 122, 111 (1981)

17 B Pointu, M Braizaz, P Poncet and J Rousseau, $J$ electroanal Chem 151, 65 (1983)

18 B Pointu, M Braizaz, P Poncet and J Rousseau, $J$ electroanal Chem 151, 79 (1983)

19 A Szucs and M Novak, $J$ electroanal Chem 210, 247 (1986)

20 D Dickertmann, F D Koppitz and J W Schultze, Electrochum Acta 21, 967 (1976)

$21 \mathrm{~J} M$ Sánchez-Marin and $J \mathbf{M}$ Las Heras, Conocimiento de Materiales (in Spanish), Ch 44 Editonal Donostiarra, San Sebastıán, Spann (1982)

22 H D Speckmann, $M$ M Lohrengel, J W Schultze and H H Strehblow, Ber Bunsenges Phys Chem 89, 392 (1985)

23 Encyclopedia of Electrochemustry of the Elements, Vol II (Edited by A J Bard) Marcel Dekker, New York (1976)

24 P Pascal, Noveau Tranté de Chimie Minérale, Vol III, p 344 Masson et Cre, Pans (1957)

25 D V Vásquez Moll, $M$. $R$ G de Chialvo, $R$ C Salverezza and A J Arvia, Electrochim Acta 30, 1011 (1985)

26 M R G de Chalvo, D V Vásquez Moll, R C. Salverezza and A J Arvia, Electrochum Acta 30, 1501 (1985)

27 R C Salvarezza, D V Vásquez Moll and A J Arvia, Electrochim Acta 32, 1421 (1987)

28 D V Vásquez Moll, R. C Salvarezza, $H$ Videla and A J Arvia, $J$ electrochem Soc 132, 754 (1985)

29 W Davison and J A Harnson, J electroanal Chem 44, 213 (1973)

30 B Schanfker and G Hulls, Electrochm Acta 28, 879 (1983)

31 R J Nichols, O M Magnussen, J Hotlos, T Twomey, R J Behm and D M Kolb, J electroanal Chem 290, $21(1990)$ 